\title{
Phagocyte activity reflects mammalian homeo- and hetero-thermic physiological states
}

Jiri Pikula ${ }^{12^{*}} \mathbb{D}$, Tomas Heger ${ }^{1 *}$, Hana Bandouchova ${ }^{1}$, Veronika Kovacova ${ }^{1}$, Monika Nemcova', Ivana Papezikova ${ }^{1}$, Vladimir Piacek', Renata Zajíčkováa ${ }^{3,4}$ and Jan Zukal ${ }^{3,5}$

\begin{abstract}
Background: Emergence of both viral zoonoses from bats and diseases that threaten bat populations has highlighted the necessity for greater insights into the functioning of the bat immune system. Particularly when considering hibernating temperate bat species, it is important to understand the seasonal dynamics associated with immune response. Body temperature is one of the factors that modulates immune functions and defence mechanisms against pathogenic agents in vertebrates. To better understand innate immunity mediated by phagocytes in bats, we measured respiratory burst and haematology and blood chemistry parameters in heterothermic greater mouse-eared bats (Myotis myotis) and noctules (Nyctalus noctula) and homeothermic laboratory mice (Mus musculus).

Results: Bats displayed similar electrolyte levels and time-related parameters of phagocyte activity, but differed in blood profile parameters related to metabolism and red blood cell count. Greater mouse-eared bats differed from mice in all phagocyte activity parameters and had the lowest phagocytic activity overall, while noctules had the same quantitative phagocytic values as mice. Homeothermic mice were clustered separately in a high phagocyte activity group, while both heterothermic bat species were mixed in two lower phagocyte activity clusters. Stepwise regression identified glucose, white blood cell count, haemoglobin, total dissolved carbon dioxide and chloride variables as the best predictors of phagocyte activity. White blood cell counts, representing phagocyte numbers available for respiratory burst, were the best predictors of both time-related and quantitative parameters of phagocyte activity. Haemoglobin, as a proxy variable for oxygen available for uptake by phagocytes, was important for the onset of phagocytosis.
\end{abstract}

Conclusions: Our comparative data indicate that phagocyte activity reflects the physiological state and blood metabolic and cellular characteristics of homeothermic and heterothermic mammals. However, further studies elucidating trade-offs between immune defence, seasonal lifestyle physiology, hibernation behaviour, roosting ecology and geographic patterns of immunity of heterothermic bat species will be necessary. An improved understanding of bat immune responses will have positive ramifications for wildlife and conservation medicine.

Keywords: Bats, Torpor, Innate immunity, Blood, Phagocytosis, Respiratory burst

\footnotetext{
*Correspondence: pikulaj@vfu.cz; hegert4@gmail.com

'Department of Ecology and Diseases of Zoo Animals, Game, Fish and Bees,

University of Veterinary and Pharmaceutical Sciences Brno, Palackého trída

1946/1, 61242 Brno, Czech Republic

Full list of author information is available at the end of the article
}

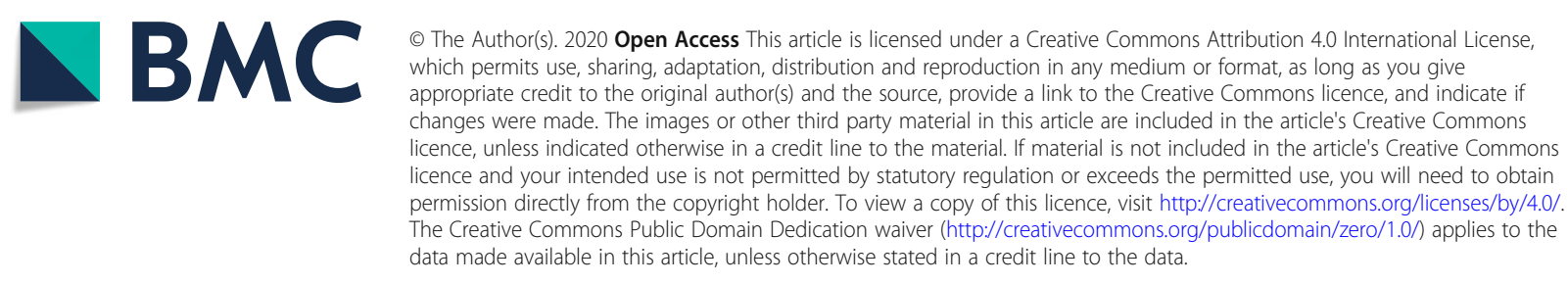




\section{Background}

Phagocytosis is a protective mechanism linking innate and adaptive immune responses [1, 2]. The primary function of phagocytes is to recognise, engulf and destroy pathogenic agents, infected or dead cells and foreign particles. For this purpose, phagocytes are recruited to sites of infection, tissue damage or irritation by foreign particles. In order to produce potent microbicidal agents, such as reactive oxygen and nitrogen species (ROS, RNS), phagocytes gain energy from the catabolism of glucose and thereby considerably increase the uptake of oxygen [2]. In addition to their fundamental function in the innate immune system, ROS and RNS also modulate adaptive immune responses. While techniques to measure phagocyte activity through respiratory burst have relevance for clinical medicine $[2,3]$, they can also be employed in comparative and ecological immunology $[4,5]$.

Phagocytic cells of the mammalian immune system include monocytes and macrophages, dendritic cells, neutrophils and other granulocytes [1]. A host's ability to defend against pathogens can be evaluated using either separate cell types or all phagocytes present in whole blood. With the latter option, micro-method procedures allow for the examination of small wildlife species [6]. The magnitude of respiratory burst is enhanced by priming of phagocytes by previous exposure to microorganisms and depends on the total and differential count of cells $[3,6]$.

Another important factor modulating immune function is temperature. In homeotherms, the costs associated with mounting an immune response are traded against thermoregulation $[7,8]$, while phagocyte activity varies with conditions associated with thermal acclimatisation in poikilotherms [4]. Likewise, expression of both daily heterothermy [9] and winter torpor/arousal bouts [10] have profound effects on immune defence.

Some highly pathogenic zoonotic agents circulate in bats without causing severe infections in these reservoir hosts [11]. On the other hand, temperate bat species populations are threatened by a fungal skin disease [12]. Greater insights into bat immune defence mechanisms are therefore needed.

In general, the annual cycle of temperate insectivorous bat species comprises 1) a period of food availability when active bats maintain homeothermy, and 2) a winter period when bats minimise their metabolic needs through torpor [13]. Hibernation temperatures in temperate vespertilionid and rhinolophid bats range from 0 to $12{ }^{\circ} \mathrm{C}[14,15]$ and, during torpor, the bats lower their body temperature close to the ambient temperature, together with reductions in metabolic, heart and respiratory rates [16]. Bats have adapted to profound changes in their metabolism, oxygen consumption and other physiological functions at the organismal, organ, cellular and molecular levels to cope with the cycles of torpor and arousal [17-19]. Regulation of body temperature is not that simple in temperate bats, however, and bats are also known to use daily torpor in order to save energy and water at cold ambient temperatures and during periods of food scarcity in their active and/or reproductive seasons [20, 21]. Moreover, in addition to rewarming periodically to euthermy, hibernating bats may also display heterothermic, and even cold arousals [16, 22]. Irregular periodicity in the torpor/arousal cycle means that bats will be in different physiological states when undergoing prolonged torpor, rewarming from torpor, euthermy or cooling into torpor [16]. Physiological characteristics associated with the role of low hibernation body temperature in phagocyte respiratory burst response include 1) a decrease in the level of blood glucose $[23,24]$; 2) lowered oxygen availability for phagocyte respiratory burst due to lowered venous and arterial blood partial pressure of oxygen, a higher oxygen affinity to haemoglobin [25], and long periods of apnoe [26]; 3) torpor induced leukopenia/neutropenia [27, 28]; and 4) altered activity of complement factors [29, 30].

In light of the above, heterotherms provide an interesting model for examining immune system function. Given that many parameters impacting phagocyte respiratory burst are altered during torpor, we predict lowered phagocyte respiratory burst performance in heterothermic animals compared with homeotherms. We performed a functional comparative study to confirm this by sampling blood from heterothermic greater mouse-eared bats (Myotis myotis) and noctules (Nyctalus noctula) and homeothermic laboratory mice (Mus musculus), evaluating phagocyte activity in combination with standard haematology and blood chemistry as predictors of both time-related and quantitative parameters of respiratory burst.

\section{Results}

With the exception of total dissolved carbon dioxide $\left(\mathrm{tCO}_{2}\right)$ and total phagocyte capacity (Integral), the three mammal species in this study differed in all blood profile and phagocyte respiratory burst parameters (Table 1), with post-hoc comparisons confirming species-specific differences in different parameters. The two bat species had similar electrolyte levels $(\mathrm{Na}, \mathrm{K})$ and time-related parameters of phagocyte activity $\left(\mathrm{T}_{\text {start }}, \mathrm{T}_{\text {end }}\right)$, but differed in blood profile parameters related to metabolism (Urea, Glu) and red blood cell count (Hct, Hb) (Figs. 1 and 2, Table 1). While heterothermic $N$. noctula bats had the same quantitative values (Peak, Integral) as laboratory mice, heterothermic $M$. myotis differed in all phagocyte activity parameters (Figs. 2 and 3, Table 1). Nevertheless, k-means clustering analysis clearly separated all laboratory 


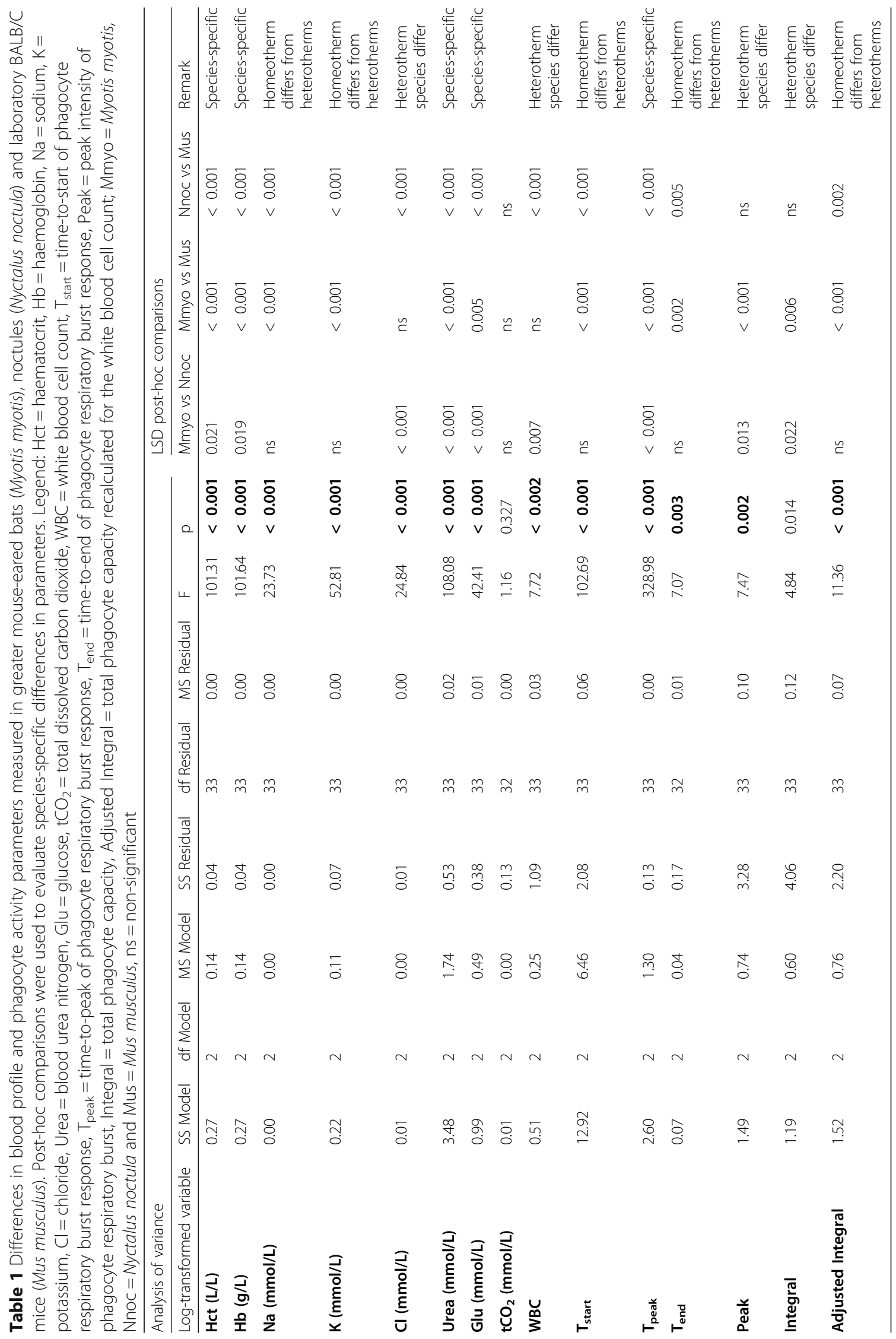



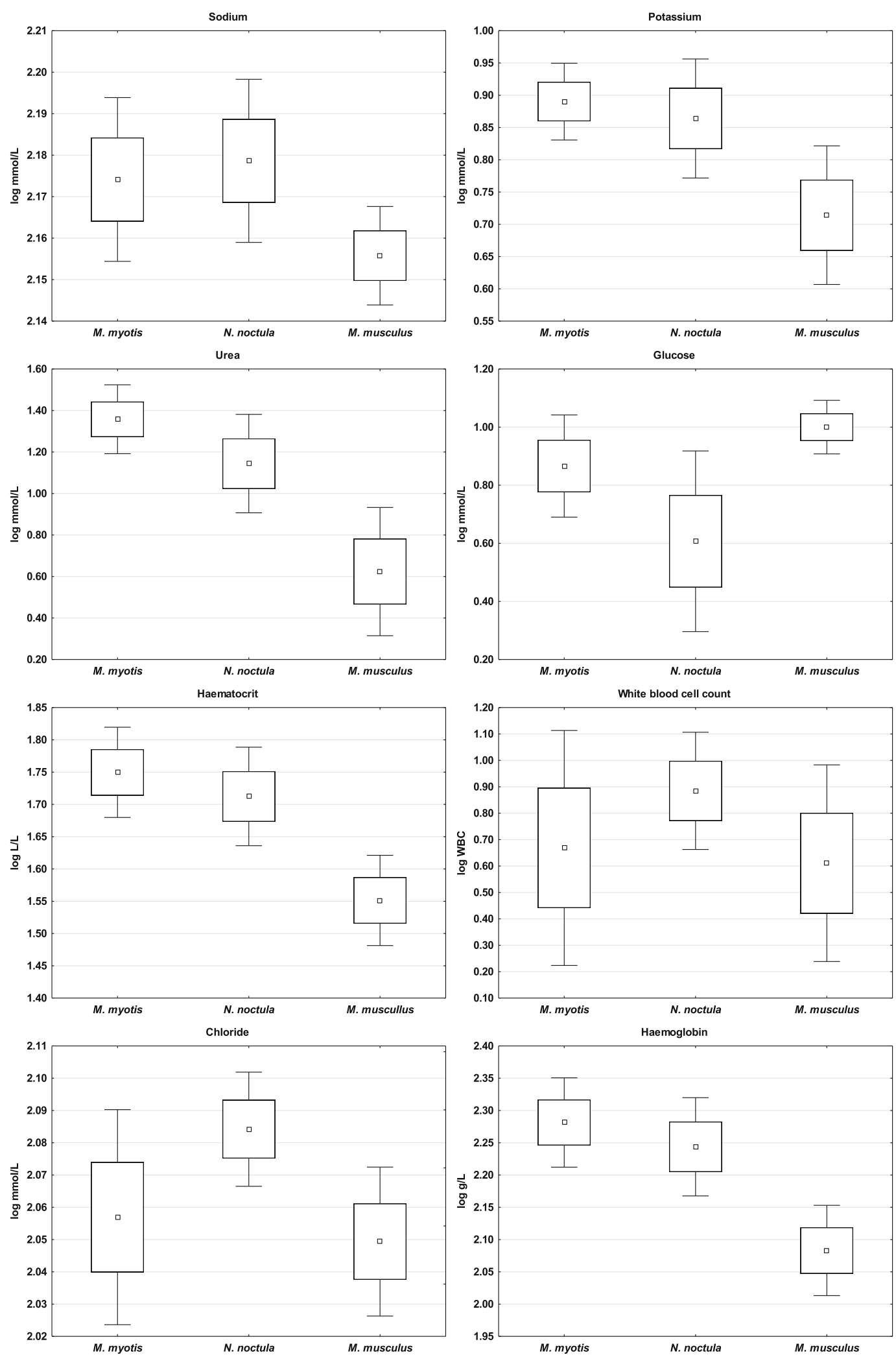

Fig. 1 Differences in blood profile parameters measured in homeothermic mice and heterothermic bats. Blood collection was performed from Myotis myotis and Nyctalus noctula bats and laboratory mice at body temperatures of $25^{\circ} \mathrm{C}$ and $38^{\circ} \mathrm{C}$ reflecting their respective physiological states 


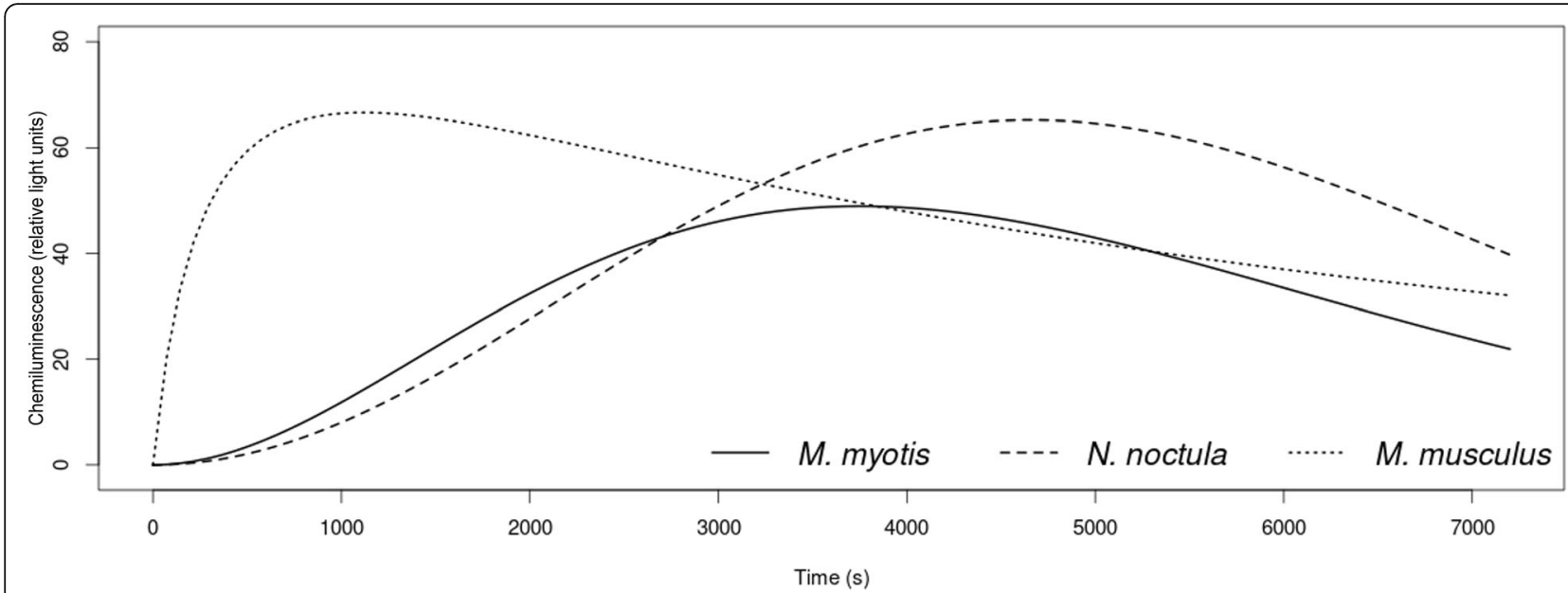

Fig. 2 Phagocyte activity kinetics in homeothermic mice and heterothermic bats. Chemiluminescence represents the intensity of respiratory burst of phagocytes over time. Luminometric detection was performed at cell incubation temperatures of $25^{\circ} \mathrm{C}$ for Myotis myotis and Nyctalus noctula bats and $38^{\circ} \mathrm{C}$ for laboratory mice, reflecting their physiological state based on body temperature measurements at the time of blood collection

mice specimens from bats at the highest Euclidean distance $(0.382$ "high phagocytic activity group, cluster 2" and 0.519 "low phagocytic activity group, cluster 3", respectively). The splitting of bats into two additional clusters (2 and 3; Euclidean distance 0.279) was not driven by species specificity but mainly by parameters related to white blood cell count (WBC) and phagocyte respiratory burst (Table 2).

All predictive regression models were statistically highly significant and, with the exception of variables $\mathrm{T}_{\text {end }}$ and Adjusted Integral (AI) that had lower coefficients of determination, there was a good fit with the data (Table 3). Forward and backward stepwise regression both showed differences in the factors explaining quantitative and time-related phagocyte activity parameters. Quantitative phagocyte activity parameters (Peak, Integral, Adjusted Integral) were positively correlated with white blood cell count and negatively with haemoglobin concentration (Table 3, Fig. 4a), while timerelated parameters $\left(\mathrm{T}_{\text {start }}, \mathrm{T}_{\text {peak }}\right)$ were positively influenced by haemoglobin concentration (Table 3, Fig. $4 \mathrm{~b}$ ). The time-to-end response ( $\left.T_{\text {end }}\right)$ differed from the other time-related parameters in being influenced by the same factors as the quantitative parameters.

\section{Discussion}

Both functional competence of the host immune system and microbial virulence determine whether an infection becomes established or is cleared following interaction between the host and a pathogen [31]. As phagocyte respiratory burst is a crucial part of the host's innate defence mechanism [2], it is supposed to work efficiently in the metabolic and cellular milieu of blood regulated by homeostatic mechanisms. However, microorganisms have evolved in parallel to the evolution of the host's immune system, and display a variety of mechanisms for evading phagocytic destruction [32].

Here, we show a high-to-low gradient of differential phagocyte activity performance in homeotherms and heterotherms. While multivariate analysis clustered homeothermic laboratory mice in a high phagocyte activity group, both heterothermic bat species were mixed in two lower phagocyte activity clusters, though our data indicate that $N$. noctula were clustered closer to homeothermic laboratory mice, as manifested by similar quantitative values of phagocyte respiratory burst. We can only speculate that noctules require a higher phagocytic activity set point during torpor because they hibernate in roosts subject to more rapid temperature changes compared with the more stable cave environment utilised by M. myotis [33-35].

Despite significant multi- and uni-variate differences in blood profile and phagocyte respiratory burst parameters, it was possible to formulate general predictions based on the data from the homeothermic and heterothermic mammals examined, with stepwise regressions identifying relevant blood profile variables (i.e. glucose, white blood cell count, haemoglobin, total dissolved carbon dioxide and chloride) as predictors of phagocyte activity. While resting phagocytes are low in metabolism, activation of respiratory burst triggers oxygen and energy consumption [2]. In the present study, heterothermic bats displayed significantly lower blood glucose levels than the laboratory mice. Interestingly, a negative relationship between glucose and time-related phagocyte activity parameters was observed, but not statistically significant after $p$-value correction. This finding suggests either a low glucose level threshold for respiratory burst 

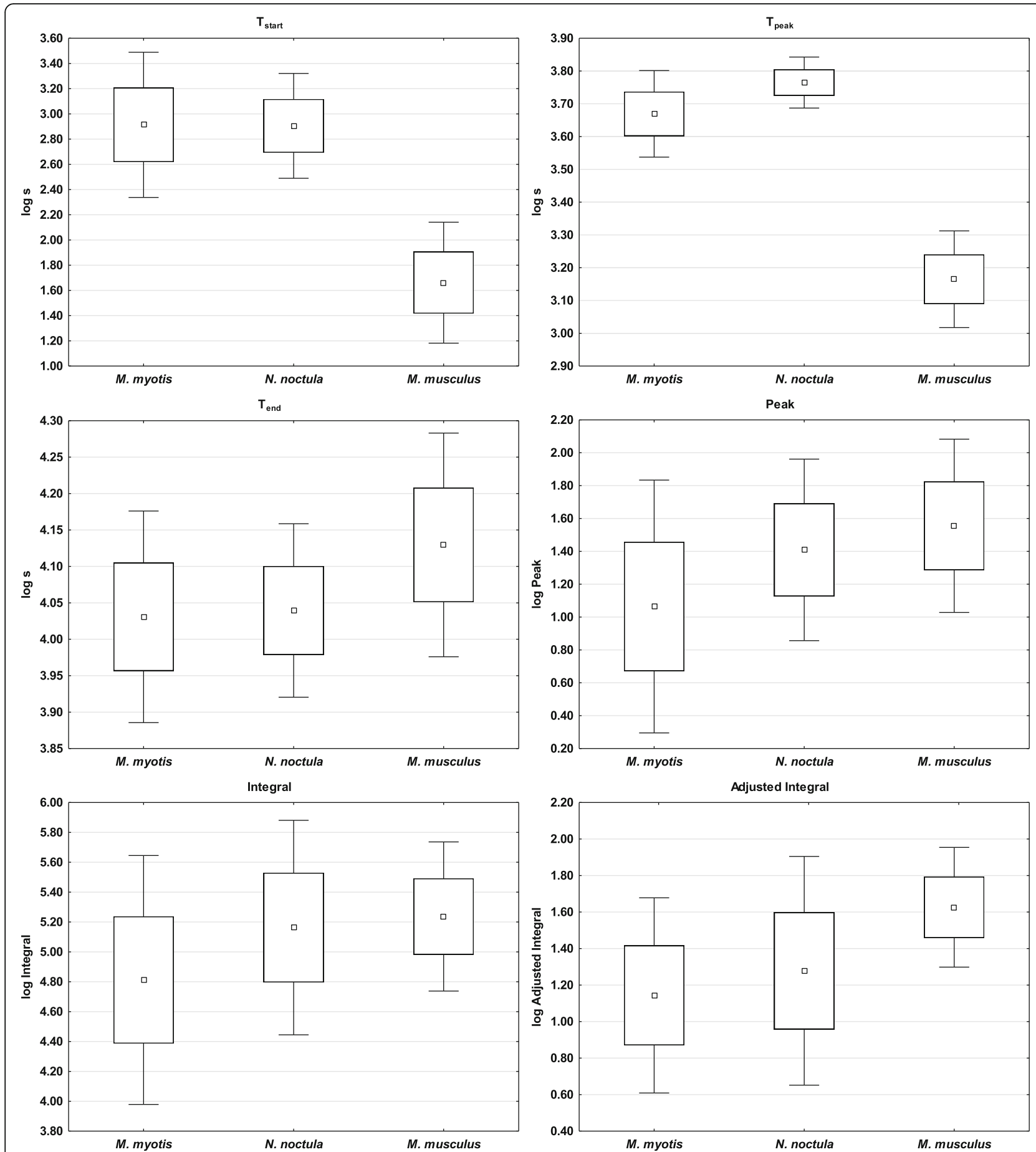

Fig. 3 Differences in phagocyte respiratory burst parameters measured in homeothermic mice and heterothermic bats. Legend: $T_{\text {start }}=$ time-tostart of phagocyte respiratory burst response, $T_{\text {peak }}=$ time-to-peak of phagocyte respiratory burst response, $T_{\text {end }}=$ time-to-end of phagocyte respiratory burst response, Peak = peak intensity of phagocyte respiratory burst, Integral = total phagocyte capacity, Adjusted Integral = total phagocyte capacity recalculated for the white blood cell count

or a switch of fuel sources from carbohydrates to fatty acids in hypoglycaemic torpid bats [30].

White blood cell counts, representing phagocyte numbers available for respiratory burst, proved the best predictors of both time-related and quantitative parameters of phagocyte activity. Based on flow cytometry of rodent blood, Lojek et al. [6] concluded that the majority of whole blood respiratory burst is due to neutrophils, 
Table 2 Mean values of blood profile and phagocyte activity parameters in groups defined by K-means clustering analysis of the three mammal species under study. All Mus musculus specimens separated from bats in one cluster. Bats were split between two additional groups with clustering not driven by species specificity but rather parameters related to white blood cell count and phagocyte respiratory burst. Legend: $\mathrm{Hct}=$ haematocrit, $\mathrm{Hb}=$ haemoglobin, $\mathrm{Na}=$ sodium, $\mathrm{K}=$ potassium, $\mathrm{Cl}=\mathrm{chloride}, \mathrm{Urea}=\mathrm{blood}$ urea nitrogen, $\mathrm{Glu}=$ glucose, $\mathrm{tCO}_{2}=$ total dissolved carbon dioxide, $\mathrm{WBC}=$ white blood cell count, $\mathrm{T}_{\text {start }}=$ time-to-start of phagocyte respiratory burst response, $T_{\text {peak }}=$ time-to-peak of phagocyte respiratory burst response, $T_{\text {end }}=$ time-to-end of phagocyte respiratory burst response, Peak = peak intensity of phagocyte respiratory burst, Integral = total phagocyte capacity, Adjusted Integral = total phagocyte capacity recalculated for the white blood cell count; Mmyo = Myotis myotis, Nnoc = Nyctalus noctula and Mus= Mus musculus

\begin{tabular}{|c|c|c|c|}
\hline & Cluster 1 & Cluster 2 & Cluster 3 \\
\hline Hct (L/L) & 1.551 & 1.716 & 1.744 \\
\hline $\mathrm{Hb}(\mathrm{g} / \mathrm{L})$ & 2.083 & 2.248 & 2.276 \\
\hline $\mathrm{Na}(\mathrm{mmol} / \mathrm{L})$ & 2.155 & 2.179 & 2.172 \\
\hline $\mathrm{K}(\mathrm{mmol} / \mathrm{L})$ & 0.714 & 0.878 & 0.874 \\
\hline $\mathrm{Cl}(\mathrm{mmol} / \mathrm{L})$ & 2.049 & 2.079 & 2.062 \\
\hline Urea $(\mathrm{mmol} / \mathrm{L})$ & 0.623 & 1.215 & 1.279 \\
\hline Glu (mmol/L) & 0.999 & 0.665 & 0.802 \\
\hline $\mathrm{tCO}_{2}(\mathrm{mmol} / \mathrm{L})$ & 1.374 & 1.351 & 1.342 \\
\hline WBC & 0.610 & 0.876 & 0.677 \\
\hline $\mathrm{T}_{\text {start }}$ & 1.661 & 2.759 & 3.071 \\
\hline$T_{\text {peak }}$ & 3.164 & 3.727 & 3.709 \\
\hline$T_{\text {end }}$ & 4.129 & 4.078 & 3.991 \\
\hline Peak & 1.555 & 1.526 & 0.936 \\
\hline Integral & 5.236 & 5.310 & 4.650 \\
\hline Adjusted Integral & 1.626 & 1.434 & 0.973 \\
\hline Individuals in the cluster & Mus1-13 & $\begin{array}{l}\text { Mmyo3,21-23 } \\
\text { Nnoc1,4-7,9,10,12 }\end{array}$ & $\begin{array}{l}\text { Mmyo 1,2,5 -7,10,12 } \\
\text { Nnoc2,3,8,11 }\end{array}$ \\
\hline
\end{tabular}

the most abundant and potent phagocytes and the first cells recruited to sites of infection [24, 36, 37]. During torpor, the numbers of all white blood cell types in circulation decrease considerably [27]; surprisingly, however, the homeothermic mice in this study displayed the lowest white blood cell count. While neutrophils are subject to margination in blood vessels during torpor, their numbers are usually restored rapidly as heterothermic individual re-warm upon arousal [28].

Blood haemoglobin concentration in this study was considered as a proxy variable for oxygen available for uptake by phagocytes [2]. Compared with the laboratory mice, both bat species displayed higher haematocrit and haemoglobin levels, suggesting an extraordinary oxygen-

Table 3 Stepwise multiple regression models predicting parameters of phagocyte activity in greater mouse-eared bats (Myotis myotis), noctules (Nyctalus noctula) and laboratory BALB/C mice (Mus musculus). Legend: $\mathrm{Hb}=$ haemoglobin, $\mathrm{Cl}=\mathrm{chloride}, \mathrm{Glu}=$ glucose, $\mathrm{tCO}_{2}=$ total dissolved carbon dioxide, $\mathrm{WBC}=$ white blood cell count, $\mathrm{T}_{\text {start }}=$ time-to-start of phagocyte respiratory burst response, $T_{\text {peak }}=$ time-to-peak of phagocyte respiratory burst response, $T_{\text {end }}=$ time-to-end of phagocyte respiratory burst response, Peak = peak intensity of phagocyte respiratory burst, Integral = total phagocyte capacity, Adjusted Integral = total phagocyte capacity recalculated for the white blood cell count; ${ }^{*}=p<0.05$ (not significant after Bonferroni correction), ${ }^{* *}=p<0.01,{ }^{* * *}=p<0.001$

\begin{tabular}{|c|c|c|c|c|c|c|}
\hline \multirow{2}{*}{$\begin{array}{l}\text { Phagocyte activity parameters } \\
\text { Time-related }\end{array}$} & \multirow[t]{2}{*}{ Intercept } & \multicolumn{4}{|c|}{ Predicting model parameters } & \multirow[t]{2}{*}{ Multiple R2 } \\
\hline & & & & & & \\
\hline $\mathrm{T}_{\text {start }}$ & $-8.680^{* * *}$ & $-0.849 \mathrm{Glu}^{*}$ & $5.531 \mathrm{Hb}^{* * *}$ & -0.419 WBC & & 0.87 \\
\hline$T_{\text {peak }}$ & -4.438 & $1.840 \mathrm{Cl}$ & $-0.360 \mathrm{Glu}^{*}$ & $2.028 \mathrm{Hb}^{* * *}$ & & 0.88 \\
\hline$T_{\text {end }}$ & $4.273^{* * *}$ & $0.370 \mathrm{tCO}_{2}{ }^{*}$ & $0.121 \mathrm{Glu}$ & $-0.426 \mathrm{Hb}^{* *}$ & $0.184 \mathrm{WBC}^{* *}$ & 0.56 \\
\hline \multicolumn{7}{|l|}{ Quantitative } \\
\hline Peak & -0.478 & $3.739 \mathrm{Cl}$ & $-2.972 \mathrm{Hb}^{* * *}$ & $0.889 \mathrm{WBC}^{* * *}$ & & 0.76 \\
\hline Integral & $9.774^{* * *}$ & $-2.505 \mathrm{Hb}^{* * *}$ & $1.103 \mathrm{WBC}^{* * *}$ & & & 0.70 \\
\hline Adjusted Integral & $6.754^{* * *}$ & $-2.463 \mathrm{Hb}^{* * *}$ & & & & 0.58 \\
\hline
\end{tabular}




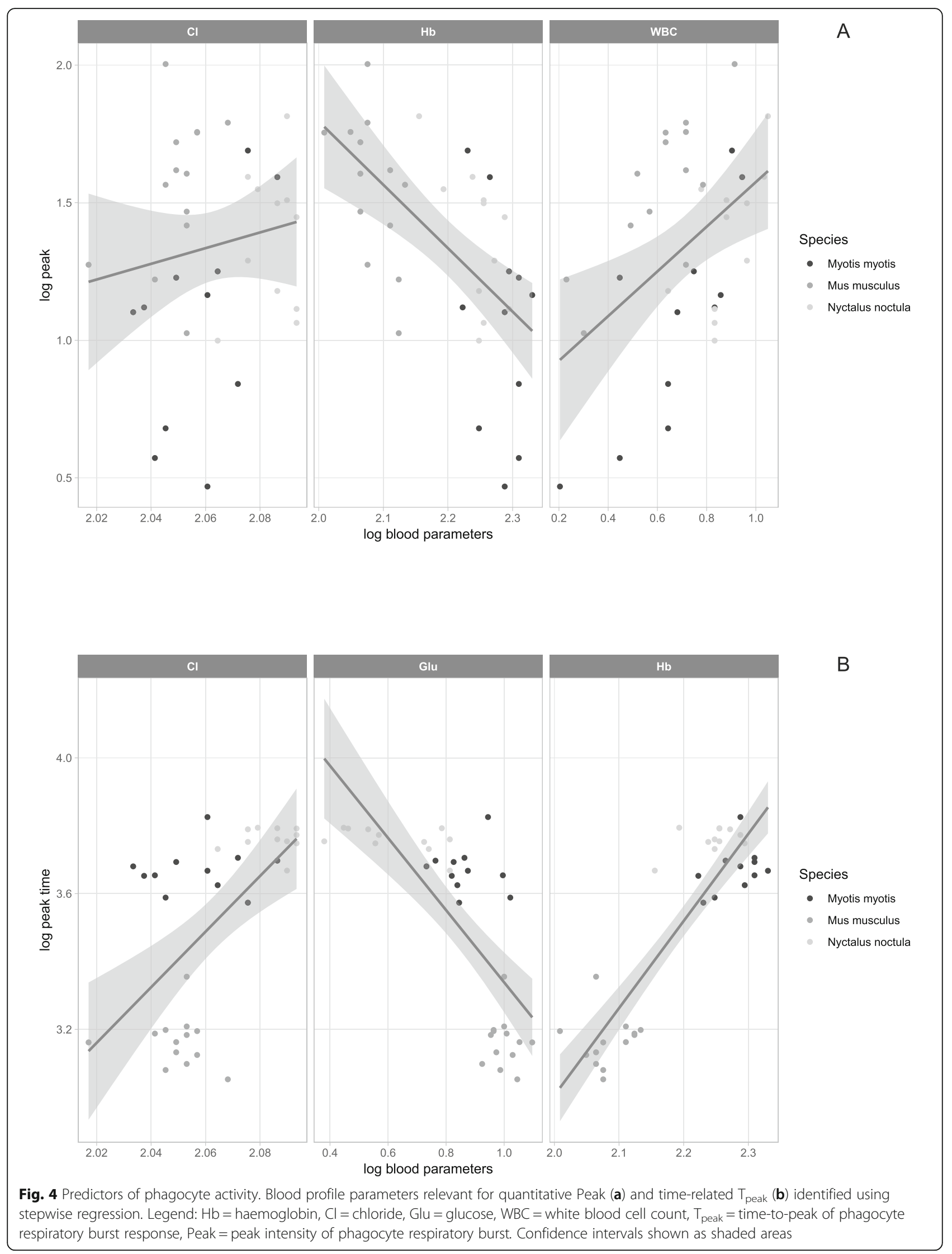


carrying capacity [25, 38, 39]. Haemoglobin concentration, as an indicator of oxygen availability, correlated with the onset of phagocytosis, i.e. the time-related respiratory burst parameters $\mathrm{T}_{\text {start }}$ and $\mathrm{T}_{\text {peak }}$ (Table 3, Fig. 4b); surprisingly, however, we recorded a negative relationship between haemoglobin and $\mathrm{T}_{\text {end }}$ and all quantitative phagocyte activity variables. This unexpected finding may have been due to an increased affinity of haemoglobin for oxygen at lower temperatures in torpid bats [25], the quenching effect of haemoglobin [40] and/ or scavenging of hydrogen peroxide by catalase produced by red blood cells [41].

As a principal extracellular fluid electrolyte, the chloride anion is critical for maintaining water and acid-base balance, with the kidneys regulating blood chloride concentrations within a narrow range. Chloride also features in the respiratory burst reaction, where it is catalysed by phagocyte myeloperoxidase to generate chlorinating oxidants such as hypochlorous acid [42, 43]. Though not statistically significant, the chloride variable was included in the model predicting the phagocyte activity parameters $T_{\text {peak }}$ and Peak. In bats infected by the white-nose syndrome fungus (Pseudogymnoascus destructans) and amphibians affected by chytridiomycosis, chloride loss through damaged skin may thus be a factor modulating phagocytic activity and reducing their innate defences $[44,45]$.

Important issues in this type of study are the blood collection technique employed and the time required for sample processing. While some haematology and serum chemistry parameters may alter in response to physical restraint during blood collection [46], stress associated with short-term capture and handling has little adverse effect on innate immune parameters [47]. Further, as blood cells continue to consume glucose and phagocytes can still be activated in the stored blood sample [6], we used an on-site analyser to measure blood profile parameters immediately following collection, with subsequent examination of phagocyte respiratory burst taking place in the laboratory within one hour. Hence, we are satisfied that our readings provide an accurate representation of the factors associated with phagocyte respiratory burst in homeothermic and heterothermic small mammals.

Both the duration and thermal profile of hibernation, as well as daily torpor utilisation, can have a significant influence on the activity of pathogenic agents [48-50]. It has been suggested that mammalian endothermy and homeothermy have evolved as trade-offs between metabolic costs and avoidance of the temperature preference ranges of many microorganisms [51]. The hibernation behaviour of bats infected with the psychrophilic whitenose syndrome fungus, for example, may modulate defence mechanism function in two ways: 1) they may show a fever response, meaning that they re-warm to a higher temperature during arousal [52] and 2) their choice of hibernation temperature could have an impact on fungal growth rate, infection intensity, pathophysiology and the ultimate outcome of the skin disease [24].

Phagocytes produce reactive oxidants to destroy pathogens; however, these can induce self-damage as well. Indeed, oxidative stress is frequently associated with pathogenesis of infections and immunopathology of chronic inflammation [53-55]. Bats are relatively unique in their ability to mitigate oxidative stress associated with increased oxidant generation during flight and immune response to intracellular infection [56, 57], with antioxidant mechanisms appearing to contribute to the bat's reservoir status, allowing them to tolerate pathogens highly virulent to other mammalian species, including humans [11, 58]. Using an in vitro comparative experiment with $M$. myotis bone marrow-derived macrophages and laboratory mice, Kacprzyk et al. [59] demonstrated that bat cells, unlike murine cells, show a balanced pro- and anti-inflammatory response following artificial immunity challenge. As noted in Palearctic hibernating bat species infected with the white-nose syndrome fungus, longer-term co-evolution in regions of pathogen endemicity may also promote disease tolerance to extracellular agents $[49,60]$. Unlike Palearctic bats, North American bats show a dysregulated immune response to white-nose syndrome early in the posthibernation period [61]. The results of the present study suggest that pathogen tolerance in hibernating bats may be associated with decreased phagocyte respiratory burst rather than mitigation of adverse effects associated with phagocyte activation [62], with tolerance mechanisms associated with lower immune activity protecting the infected host from damage by both the pathogen and the immune system. As tolerance has little direct negative effect on the infectious agent, this promotes the reservoir status of bats, with consequences for host-pathogen co-evolution [63].

We sampled early post-hibernation $M$. myotis and $N$. noctula bats captured in their hibernacula for the comparison with the laboratory mouse as a standard immunological model matching both bat species in size and predicted that body temperature is the main driver of phagocyte activity. Our study design based on sampling bat species at different hibernacula without spatial replication, however, might confound comparative results. Bat species used in the study utilize different roosting strategies, meaning that they never meet in the same shelter type. It is clear that there is spatial variation in immune defences [64], however, both bat species are not sedentary to allow for easy inference of spatial immunity patterns. Myotis myotis bat is a regionally migrating species with regular movements associated with its annual life-cycle of about $150 \mathrm{~km}$. Individuals sampled in a specific hibernaculum are aggregated there randomly from 
a large geographic region [65, 66]. Likewise, Nyctalus noctula is a migratory bat species with movements to hibernacula of $1000 \mathrm{~km}$ or even longer [67]. The measured immune responses of non-sedentary bat species thus probably reflect greater spatial variation. Lacking comprehensive knowledge about other (transitional and summer) roosting sites of sampled individuals and their exposure to factors of environmental variation and pathogen load $[68,69]$, it was impossible to adopt a study design to decipher the contribution of particular roosting ecology to the immune function.

\section{Conclusions}

Emergence of both viral zoonoses from bats and diseases that threaten bat populations has highlighted the necessity for greater insights into the functioning of the bat immune system [12, 70-72]. Particularly when considering hibernating temperate bat species, it is important to understand the seasonal dynamics associated with immune response. In this study, we provide comparative functional data suggesting that phagocyte activity, as an essential mechanism of innate immunity, reflects the physiological state and blood metabolic and cellular characteristics of homeothermic and heterothermic mammals. Further studies will be necessary to elucidate trade-offs between immune competence, seasonal lifestyle physiology, hibernation behaviour, roosting ecology and geographic patterns of immunity in heterothermic bat species.

\section{Methods}

\section{Blood sampling and measurement}

We used bat heterotherms and laboratory mice for the comparative study of phagocyte respiratory burst. Each bat and mouse was handled in the least stressful manner possible by a trained veterinarian in order to obtain non-terminal samples. A total of 14 adult BALB/c (Bagg and Albino) laboratory mice of equal sex ratio were purchased from a commercial breeder (Velaz, Prague, Czech Republic). In a facility accredited for housing laboratory rodents (University of Veterinary and Pharmaceutical Sciences Brno, Czech Republic), mice were kept under standard conditions in boxes for rodents using wood shavings as bedding. Experimental mice were fed granules for rodents, a mixture of seeds, meadow grass and hay and were provided with drinking water ad libitum. Blood samples were collected from the saphenous vein of mice without anaesthesia [73]. During the early posthibernation period (April), we sampled 11 specimens of M. myotis, a cave-dwelling hibernator, and 12 specimens of $N$. noctula, a rock-crevice-dwelling and/or tree-hole hibernator, i.e. two bat species with different hibernation behaviour. Wild Myotis myotis bats were netted emerging from the Sloupsko-Šošůvské caves [49.4104556 N,
16.7390147E]. N. noctula bats, rescued as a colony from a building in Ivanovice na Hané [49.3054183 N, 17.0934306E], were submitted to a wildlife rescue centre in the Department of Ecology and Diseases of Game, Fish and Bees, University of Veterinary and Pharmaceutical Sciences Brno, Czech Republic. After skin disinfection with alcohol, $120 \mu \mathrm{l}$ blood samples were taken from bats by puncturing the uropatagial vessel using a sterile needle, the sample being collected using a heparinised pipette tip [24, 74]. The puncture site was then compressed and sealed with a drop of surgical tissue glue (Surgibond, SMI AG, Belgium) to stop bleeding. Prior to release, the bats were administered with a subcutaneous dose of Ringer's lactate solution and $5 \%$ glucose to replace energy and fluids. All bats were released at the site of capture and/or rescue within one hour of capture for blood sampling, while mice remained alive in the laboratory.

An i-STAT portable clinical analyser for veterinary use (EC8+ diagnostic cartridge, Abaxis, Union City, CA, USA) was used to measure blood profile parameters based on electrochemical sensing technologies, i.e. haematocrit (Hct, L/L), haemoglobin ( $\mathrm{Hb}, \mathrm{g} / \mathrm{L})$, sodium $(\mathrm{Na}, \mathrm{mmol} / \mathrm{L})$, potassium $(\mathrm{K}, \mathrm{mmol} / \mathrm{L})$, chloride $(\mathrm{Cl}, \mathrm{mmol} / \mathrm{L})$, blood urea nitrogen $(\mathrm{BUN}, \mathrm{mmol} / \mathrm{L})$, glucose $(\mathrm{Glu}, \mathrm{mmol} / \mathrm{L})$ and total dissolved carbon dioxide ( $\mathrm{tCO} 2, \mathrm{mmol} / \mathrm{L})$. Blood cell counts were enumerated using a Nihon Kohden MEK$5208 \mathrm{~K}$ cell counter (Nihon Kohden Corporation, Tokyo, Japan). A Romanowsky-stained blood smear was prepared to count white blood cell differential.

Respiratory burst response in both bats and laboratory mice was evaluated using luminol-enhanced chemiluminescence as a measure of phagocyte activity, as described previously $[5,75]$. The reaction mixture contained blood diluted 1:50 in Hank's balanced salt solution, luminol (Sigma-Aldrich Merck KGaA, Darmstadt, Germany) dissolved in borate buffer, and Zymosan A (Sigma-Aldrich Merck KGaA, Darmstadt, Germany). Zymosan A concentration in the reaction mixture was $0.25 \mathrm{mg} / \mathrm{ml}$. Chemiluminescence kinetics were measured for two hours at two different temperatures using a Cytation $3 \mathrm{M}$ reader (BioTek Instruments, Inc., Winooski, VT, USA). To reflect the body temperature of bats re-warming from daily torpor and mammals maintaining homeothermy, luminometric detection was performed at cell incubation temperatures of $25^{\circ} \mathrm{C}$ for bats and $38^{\circ} \mathrm{C}$ for laboratory mice, reflecting their physiological state based on body temperature measurements at the time of blood collection [24].

\section{Data analysis}

Based on the chemiluminescence data, we calculated the following fundamental respiratory burst parameters: time-to-start of response (Tstart), time-to-peak response 
(Tpeak), time-to-end of response (Tend), peak intensity (Peak) and total capacity (Integral, I). The total capacity value was also adjusted to the white blood cell count (Adjusted Integral, AI). Normal distribution of variables was tested using the Kolmogorov-Smirnov and ShapiroWilk tests. Variables that were not normally distributed were $\log$ transformed and re-checked for normality. After transformation, all parameters were normally distributed with a statistical significance threshold set at 0.01 due to the low subsample size. The log-transformed datasets (Table S1) were used for all subsequent statistical analyses. Univariate ANOVA with $p$-value corrected by Bonferroni correction was used to test the differences between species with LSD (Fisher's Least Significant Difference) post-hoc test identifying which pairs of species were statistically different. We defined the resultant clusters to the highest level of distinction using k-means clustering on pooled blood profile and phagocyte activity parameters. The expected number of clusters for each calculation was defined as the number of species (three), with missing parameter values being substituted by means.

The effect of blood profile parameters on phagocyte activity was estimated using multiple regressions, with both the response variables and explanatory variables logtransformed to achieve additivity of effects and to increase homogeneity of variance in the response variables. The predictive model was selected using stepwise selection with bidirectional elimination, using Akaike information criterion (AIC) at each step. The significance of a particular variable in the final model was checked by partial Ftest with Bonferroni correction of $p$-value. Bidirectional elimination is essentially a forward selection procedure but with the possibility of deleting a selected variable at each step when there are correlations between variables, as in backward elimination [76]. Statistical analysis was performed in Statistica for Windows v. 13.3 or in R software using the support package mass [77].

\section{Supplementary information}

Supplementary information accompanies this paper at https://doi.org/10. 1186/s12917-020-02450-z.

Additional file 1 Table S1. Supporting information data (logtransformed) on blood parameters and phagocyte activity in Myotis myotis, Nyctalus noctula and Mus musculus.

\section{Abbreviations}

Adjusted Integral: total capacity respiratory burst adjusted to the white blood cell count; ANOVA: Analysis of variance; BALB/c: (Bagg and Albino) laboratory mice; BUN: Blood urea nitrogen; Cl: Chloride; Glu: Glucose; Hb: Haemoglobin; Hct: Haematocrit; Integral: Total capacity respiratory burst; K: Potassium; LSD test: Least significant difference test; Na: Sodium; Peak: Peak intensity respiratory burst; RNS: Reactive nitrogen species; ROS: Reactive oxygen species; tCO2: total dissolved carbon dioxide; Tend: Time-to-end respiratory burst; Tpeak: Time-to-peak respiratory burst; Tstart: Time-to-start respiratory burst; WBC: White blood cell count

\section{Acknowledgements}

We are grateful to Dr. Kevin Roche for his correction and improvement of the English text.

\section{Authors' contributions}

JP and JZ designed the study. JP and JZ organised sample collection in the field and laboratory with support from HB, TH, VK, MN, VP. HB, TH, VK, MN, IP, VP performed the laboratory measurements. JZ, RZ and JP analysed the data and drafted the manuscript, to which all authors contributed with critical comments. All authors have read and approved the manuscript.

\section{Funding}

This study was supported by the Czech Science Foundation (Grant No. 1720286S). The funder had no role in the study design, data analysis, and decision to publish, or preparation of the manuscript.

\section{Availability of data and materials}

The datasets used and/or analysed during the current study are available from the corresponding author on reasonable request. Log-transformed data on blood parameters and phagocyte activity accompany this published article as additional file Table $\mathbf{S 1}$.

\section{Ethics approval and consent to participate}

Fieldwork and bat sampling in the Czech Republic was performed in accordance with Czech Law No. 114/1992 on Nature and Landscape Protection, based on permits 1662/MK/2012S/00775/MK/2012 and 00356/KK 2008/AOPK issued by the Agency for Nature Conservation and Landscape Protection of the Czech Republic. All experimental procedures were approved by the Ethical Committee of the Czech Academy of Sciences (No. 169/2011) and performed in accordance with relevant guidelines and regulations. The authors of the study are authorised to design and perform animal experiments and handle free-living bats in agreement with Czech Certificate of Competency No. CZ01341 (\$15d/3, Act No. 246/1992).

Consent for publication

Not applicable.

\section{Competing interests}

The authors declare that they have no competing interests.

\section{Author details}

'Department of Ecology and Diseases of Zoo Animals, Game, Fish and Bees, University of Veterinary and Pharmaceutical Sciences Brno, Palackého trílda 1946/1, 61242 Brno, Czech Republic. ${ }^{2}$ CEITEC - Central European Institute of Technology, University of Veterinary and Pharmaceutical Sciences Brno, Brno, Czech Republic. ${ }^{3}$ Department of Botany and Zoology, Masaryk University, Kotláŕská 2, 61137 Brno, Czech Republic. ${ }^{4}$ Institute of Biostatistics and Analyses, Masaryk University, Kamenice 3, 62500 Brno, Czech Republic. ${ }^{5}$ Institute of Vertebrate Biology, Czech Academy of Sciences, Květná 8, 60365 Brno, Czech Republic.

Received: 17 October 2019 Accepted: 30 June 2020

Published online: 06 July 2020

\section{References}

1. Rosales C, Uribe-Querol E. Phagocytosis: a fundamental process in immunity. Biomed Res Int. 2017;9042851.

2. Thomas DC. The phagocyte respiratory burst: historical perspectives and recent advances. Immunol Lett. 2017;192:88-96.

3. Dahlgren C, Karlsson A. Respiratory burst in human neutrophils. J Immunol Methods. 1999;232:3-14.

4. Marnila P, Tiiska A, Lagerspetz K, Lilius EM. Phagocyte activity in the frog Rana temporaria: whole blood chemiluminescence method and the effects of temperature and thermal acclimation. Comp Biochem Phys A. 1995;111: 609-14.

5. Papežíková I, Mareš J, Vojtek L, Hyršl P, Marková Z, Šimková A, et al. Seasonal changes in immune parameters of rainbow trout (Oncorhynchus mykiss), brook trout (Salvelinus fontinalis) and brook trout $\times$ Arctic charr hybrids (Salvelinus fontinalis $\times$ Salvelinus alpinus alpinus). Fish Shellfish Immunol. 2016;57:400-5. 
6. Lojek A, Ciz M, Marnila P, Duskova M, Lilius E-M. Measurement of whole blood phagocyte chemiluminescence in the Wistar rat. J Biolum Chemilum. 1997;12:225-31.

7. Cichoń M, Chadzińska M, Ksiażek A, Konarzewski M. Delayed effects of cold stress on immune response in laboratory mice. P Roy Soc B: Biol Sci. 2002; 269:1493-7.

8. Hawley DM, DuRant SE, Wilson AF, Adelman JS, Hopkins WA. Additive metabolic costs of thermoregulation and pathogen infection. Funct Ecol. 2012;26:701-10

9. Canale $\mathrm{Cl}$, Henry P-Y. Energetic costs of the immune response and torpor use in a primate. Funct Ecol. 2011;25:557-65.

10. Field KA, Sewall BJ, Prokkola JM, Turner GG, Gagnon MF, Lilley TM, et al. Effect of torpor on host transcriptomic responses to a fungal pathogen in hibernating bats. Mol Ecol. 2018;27:3727-43

11. Mandl JN, Ahmed R, Barreiro LB, Daszak P, Epstein JH, Virgin HW, et al. Reservoir host immune responses to emerging zoonotic viruses. Cell. 2015; 160:20-35.

12. Blehert DS, Hicks AC, Behr M, Meteyer CU, Berlowski-Zier BM, Buckles EL, et al. Bat white-nose syndrome: an emerging fungal pathogen? Science. 2009;323:227.

13. Willis CKR. Trade-offs influencing the physiological ecology of hibernation in temperate-zone bats. Integr Comp Biol. 2017;57:1214-24.

14. Webb PI, Speakman JR, Racey PA. How hot is a hibernaculum? A review of the temperatures at which bats hibernate. Can J Zool. 1996;74:761-5.

15. Perry RW. A review of factors affecting cave climates for hibernating bats in temperate North America. Environ Rev. 2013;21:28-39.

16. Boyer B, Barnes B. Molecular and metabolic aspects of mammalian hibernation expression of the hibernation phenotype results from the coordinated regulation of multiple physiological and molecular events during preparation for and entry into torpor. BioScience. 1999:49:713-24.

17. Carey HV, Andrews MT, Martin SL. Mammalian hibernation: cellular and molecular responses to depressed metabolism and low temperature. Physiol Rev. 2003:83:1153-81

18. Andrews MT. Advances in molecular biology of hibernation in mammals. Bioessays. 2007;29:431-40.

19. Xu Y, Shao C, Fedorov V, Goropashnaya A, Barnes B, Yan J. Molecular signatures of mammalian hibernation: comparisons with alternative phenotypes. BMC Genomics. 2013;14:567.

20. Dietz M, Kalko EK. Seasonal changes in daily torpor patterns of free-ranging female and male Daubenton's bats (Myotis daubentonii). J Comp Physiol B. 2006;176:223-31.

21. Wojciechowski MS, Jefimow M, Tegowska E. Environmental conditions, rather than season, determine torpor use and temperature selection in large mouse-eared bats (Myotis myotis). Comp Biochem Physiol A Mol Integr Physiol. 2007;147:828-40.

22. Bartonicka T, Bandouchova H, Berkova H, Blazek J, Lucan R, Horacek I, et al Deeply torpid bats can change position without elevation of body temperature. J Therm Biol. 2017;63:119-23.

23. Roy VK, Krishna A. Changes in glucose and carnitine levels and their transporters in utero-tubal junction in relation to sperm storage in the vespertilionid bat, Scotophilus heathi. J Exp Zool Part A. 2013;319:517-26.

24. Bandouchova H, Bartonička T, Berkova H, Brichta J, Kokurewicz T, Kovacova $V$, et al. Alterations in the health of hibernating bats under pathogen pressure. Sci Rep-UK. 2018;8:6067.

25. Musacchia $X$, Volkert W. Blood gases in hibernating and active ground squirrels: $\mathrm{HbO}_{2}$ affinity at 6 and 38 C. Am J Phys. 1971;221:128-30.

26. Geiser F. Hibernation: endotherms in eLS. Chichester: Wiley, Ltd; 2011. https://doi.org/10.1002/9780470015902.a0003215.pub2.

27. Bouma HR, Carey HV, Kroese FGM. Hibernation: the immune system at rest? J Leukoc Biol. 2010;88:619-24.

28. Bouma HR, Dugbartey GJ, Boerema AS, Talaei F, Herwig A, Goris M, et al. Reduction of body temperature governs neutrophil retention in hibernating and nonhibernating animals by margination. J Leukoc Biol. 2013:94:431-7.

29. Moore MS, Reichard JD, Murtha TD, Zahedi B, Fallier R, Kunz TH. Specific alterations in complement protein activity of little brown Myotis (Myotis lucifugus) hibernating in white-nose syndrome affected sites. PLoS One. 2011:6:e27430.

30. Hecht AM, Braun BC, Krause E, Voigt CC, Greenwood AD, Czirják GÁ. Plasma proteomic analysis of active and torpid greater mouse-eared bats (Myotis myotis). Sci Rep UK. 2015;5:16604.
31. Casadevall A, Pirofski L-A. Host-pathogen interactions: redefining the basic concepts of virulence and pathogenicity. Infect Immun. 1999;67:3703-13.

32. Smith LM, May RC. Mechanisms of microbial escape from phagocyte killing. Biochem Soc T. 2013:41:475.

33. Boratynski JS, Rusiński M, Kokurewicz T, Bereszyński A, Wojciechowski MS. Clustering behavior in wintering greater mouse-eared bats Myotis myotis - the effect of micro-environmental conditions. Acta Chiropterol. 2012;14:417-24.

34. Ruczynski I, Bogdanowicz W. Roost cavity selection by Nyctalus noctula and N. leisleri (Vespertilionidae, Chiroptera) in Bialowieza primeval forest, eastern Poland. J Mammal. 2005;86:921-30.

35. Zukal J, Berková H, Řehák Z. Activity and shelter selection by Myotis myotis and Rhinolophus hipposideros hibernating in Kateřinská cave (Czech Republic). Mamm Biol. 2005;70:271-81.

36. Kruger $\mathrm{P}$, Saffarzadeh M, Weber ANR, Rieber N, Radsak M, von Bernuth $H$, et al. Neutrophils: between host defence, immune modulation, and tissue injury. PLoS Pathog. 2015;11:e1004651.

37. Pikula J, Amelon SK, Bandouchova H, Bartonička T, Berkova H, Brichta J, et al White-nose syndrome pathology grading in Nearctic and Palearctic bats. PLoS One. 2017;12:e0180435

38. Maina JN, King AS. Correlations between structure and function in the design of the bat lung: a morphometric study. J Exp Biol. 1984;111:43-61.

39. Rodríguez-Durán A, Padilla-Rodríguez E. Blood characteristics, heart mass, and wing morphology of Antillean bats. Caribb J Sci. 2008;44:375-9.

40. Glette J, Solberg CO, Lehmann V. Factors influencing human polymorphonuclear leukocyte chemiluminescence. Acta Pathol Microbiol Scandinavica C Immunol. 1982;90C:91-5.

41. Winterbourn CC, Stern A. Human red cells scavenge extracellular hydrogen peroxide and inhibit formation of hypochlorous acid and hydroxyl radical. $J$ Clin Invest. 1987:80:1486-91.

42. Chapman ALP, Hampton MB, Senthilmohan R, Winterbourn CC, Kettle AJ. Chlorination of bacterial and neutrophil proteins during phagocytosis and killing of Staphylococcus aureus. J Biol Chem. 2002;277:9757-62.

43. Gaut JP, Yeh GC, Tran HD, Byun J, Henderson JP, Richter GM, et al. Neutrophils employ the myeloperoxidase system to generate antimicrobial brominating and chlorinating oxidants during sepsis. P Natl Acad Sci USA. 2001;98:11961.

44. Cryan PM, Meteyer CU, Blehert DS, Lorch JM, Reeder DM, Turner GG, et al. Electrolyte depletion in white-nose syndrome bats. J Wildlife Dis. 2013;49: 398-402.

45. Voyles J, Berger L, Young S, Speare R, Webb R, Warner J, et al. Electrolyte depletion and osmotic imbalance in amphibians with chytridiomycosis. Dis Aquat Org. 2007;77:113-8.

46. Heard DJ, Huft VJ. The effects of short-term physical restraint and isoflurane anesthesia on hematology and plasma biochemistry in the island flying fox (Pteropus hypomelanus). J Zoo Wildl Med. 1998;29:14-7.

47. Strobel S, Becker NI, Encarnação JA. No short-term effect of handling and capture stress on immune responses of bats assessed by bacterial killing assay. Mamm Biol. 2015:80:312-5.

48. Luis AD, Hudson PJ. Hibernation patterns in mammals: a role for bacterial growth? Funct Ecol. 2006:20:471-7.

49. Martínková N, Pikula J, Zukal J, Kovacova V, Bandouchova H, Bartonička T, et al. Hibernation temperature-dependent Pseudogymnoascus destructans infection intensity in Palearctic bats. Virulence. 2018;9:1734-50.

50. Martínková N, Škrabánek P, Pikula J. Modelling invasive pathogen load from non-destructive sampling data. J Theor Biol. 2019;464:98-103.

51. Bergman A, Casadevall A. Mammalian endothermy optimally restricts fungi and metabolic costs. mBio. 2010;1:e00212-0.

52. Mayberry HW, McGuire LP, Willis CKR. Body temperatures of hibernating little brown bats reveal pronounced behavioural activity during deep torpor and suggest a fever response during white-nose syndrome. J Comp Physiol B. 2018;188:333-43.

53. Babior BM. Phagocytes and oxidative stress. Am J Med. 2000;109:33-44.

54. Costantini D, Møller AP. Does immune response cause oxidative stress in birds? A meta-analysis. Comp Biochem Phys A. 2009;153:339-44.

55. Vitula F, Peckova L, Bandouchova H, Pohanka M, Novotny L, Jira D, et al. Mycoplasma gallisepticum infection in the grey partridge Perdix perdix: outbreak description, histopathology, biochemistry and antioxidant parameters. BMC Vet Res. 2011;7:12.

56. Brook CE, Dobson AP. Bats as 'special' reservoirs for emerging zoonotic pathogens. Trends Microbiol. 2015;23:172-80. 
57. Wang L-F, Walker PJ, Poon LLM. Mass extinctions, biodiversity and mitochondrial function: are bats 'special' as reservoirs for emerging viruses? Curr Opin Virol. 2011;1:649-57.

58. Mandl JN, Schneider C, Schneider SD, Baker ML. Going to bat(s) for studies of disease tolerance. Front Immunol. 2018;9:2112.

59. Kacprzyk J, Hughes GM, Palsson-McDermott EM, Quinn SR, Puechmaille SJ, O'Neill LAJ, et al. A potent anti-inflammatory response in bat macrophages may be linked to extended longevity and viral tolerance. Acta Chiropterol. 2017:19:219-28.

60. Zukal J, Bandouchova H, Brichta J, Cmokova A, Jaron KS, Kolarik M, et al. White-nose syndrome without borders: Pseudogymnoascus destructans infection tolerated in Europe and Palearctic Asia but not in North America. Sci Rep UK. 2016;6:19829.

61. Meteyer CU, Barber D, Mandl JN. Pathology in euthermic bats with white nose syndrome suggests a natural manifestation of immune reconstitution inflammatory syndrome. Virulence. 2012;3:583-8.

62. Flieger M, Bandouchova H, Cerny J, Chudičková M, Kolarik M, Kovacova V, et al. Vitamin B2 as a virulence factor in Pseudogymnoascus destructans skin infection. Sci Rep UK. 2016;6:33200.

63. Medzhitov R, Schneider DS, Soares MP. Disease tolerance as a defence strategy. Science. 2012;335:936-41.

64. Becker DJ, Albery GF, Kessler MK, Lunn TJ, Falvo CA, Czirják GÁ, et al. Macroimmunology: the drivers and consequences of spatial patterns in wildlife immune defence. J Anim Ecol. 2020;00:1-24. https://doi.org/10.1111/ 1365-2656.13166.

65. Gaisler J, Hanák V, Hanzal V, Jarský V. Results of bat banding in the Czech and Slovak republics, 1948-2000. Vespertilio. 2003;7:3-61 (in Czech with English summary).

66. Kokurewicz T, Apoznanski G, Gyselings R, Kirkpatrick L, de Bruyn L, Haddow $J$, et al. 45 years of bat study and conservation in Nietoperek bat reserve (Western Poland). Nyctalus. 2019;3:252-69.

67. Strelkov PP. Migratory and stationary bats (Chiroptera) of the European part of the Soviet Union. Acta Zool Cracoviensia. 1969;14:93-439.

68. Allen LC, Turmelle AS, Mendonça MT, Navara KI, Kunz TH, McCracken GF, et al. Roosting ecology and variation in adaptive and innate immune system function in the Brazilian free-tailed bat (Tadarida brasiliensis). J Comp Physiol B. 2008:179:315-23.

69. Linhart P, Bandouchova H, Zukal J, Votýpka J, Kokurewicz T, Dundarova H, et al. Trypanosomes in eastern and central European bats. Acta Vet Brno. 2020;89:69-78

70. Calisher CH, Childs JE, Field HE, Holmes KV, Schountz T. Bats: important reservoir hosts of emerging viruses. Clin Microbiol Rev. 2006;19:531-45.

71. Baker ML, Schountz T, Wang L-F. Antiviral immune responses of bats: a review. Zoonoses Public Hlth. 2013;60:104-16.

72. He X, Korytár T, Zhu Y, Pikula J, Bandouchova H, Zukal J, et al. Establishment of Myotis myotis cell lines - model for investigation of host-pathogen interaction in a natural host for emerging viruses. PLoS One. 2014;9: e109795.

73. Parasuraman S, Raveendran R, Kesavan R. Blood sample collection in small laboratory animals. J Pharmacol Pharmacother. 2010;1:87-93.

74. Pikula J, Bandouchova H, Kovacova V, Linhart P, Piacek V, Zukal J. Reproduction of rescued vespertilionid bats (Nyctalus noctula) in captivity: veterinary and physiological aspects. Vet Clin North Am Exot Anim Pract. 2017:20:665-77.

75. Heger T, Zukal J, Seidlova V, Nemcova M, Necas D, Papezikova I, et al. Measurement of phagocyte activity in heterotherms. Acta Vet Brno. 2020;89:79-87.

76. Wang M, Wright J, Brownlee A, Buswell R. A comparison of approaches to stepwise regression on variables sensitivities in building simulation and analysis. Energ Buildings. 2016:127:313-26.

77. Venables WN, Riple BD. Modern applied statistics with S. 4th ed. New York. ISBN 0-387-95457-0: Springer; 2002

\section{Publisher's Note}

Springer Nature remains neutral with regard to jurisdictional claims in published maps and institutional affiliations.

\section{Ready to submit your research? Choose BMC and benefit from:}

- fast, convenient online submission

- thorough peer review by experienced researchers in your field

- rapid publication on acceptance

- support for research data, including large and complex data types

- gold Open Access which fosters wider collaboration and increased citations

- maximum visibility for your research: over $100 \mathrm{M}$ website views per year

At BMC, research is always in progress.

Learn more biomedcentral.com/submissions 